\title{
PENGARUH SUHU, WAKTU, DAN KADAR AIR PADA PIROLISIS PELEPAH KELAPA SAWIT
}

\section{EFFECT OF TEMPERATURE, PYROLYSIS TIME, AND MOISTURE CONTENT IN OIL PALM MIDRIB PYROLYSIS}

\author{
*Frist Silia, Seri Maulina \\ *Departemen Teknik Kimia, Fakultas Teknik, Universitas Sumatera Utara, Sumatera Utara \\ Jl. Almamater Kampus USU Medan 20155, Indonesia \\ *Email: frist_silia@yahoo.com
}

\begin{abstract}
Abstrak
Perkebunan kelapa sawit di Indonesia mulai berkembang pesat sejak awal tahun 80-an. Luas areal kelapa sawit Indonesia pada tahun 2013 adalah sebesar 10,4 juta ha dan meningkat 4,69\% pertahunnya. Produksi pelepah kelapa sawit adalah sebanyak 22 pelepah per pohon per tahun dengan berat daging pelepah berkisar 2,2 kg. Pelepah kelapa sawit tersusun atas selulosa, hemiselulosa, dan lignin. Selulosa, hemiselulosa, dan lignin di dalam pelepah kelapa sawit dapat dijadikan asap cair. Tujuan dari penelitian ini adalah untuk menganalisis pengaruh suhu dan waktu pirolisis terhadap rendemen dan kualitas asap cair yang dihasilkan. Proses pirolisis cacahan pelepah kelapa sawit ini dilakukan pada $150^{\circ} \mathrm{C}, 200^{\circ} \mathrm{C}$, dan $250^{\circ} \mathrm{C}$ dengan variasi waktu 30 menit, 60 menit, 90 menit. Dari hasil penelitian diperoleh rendemen asap cair cenderung menurun dengan meningkatnya suhu pirolisis dalam waktu pirolisis yang sama dan rendemen asap cair cenderung meningkat dengan meningkatnya waktu pirolisis dengan suhu pirolisis yang sama. Rendemen asap cair tertinggi suhu pirolisis $150{ }^{\circ} \mathrm{C}$ dengan waktu pirolisis selama 120 menit yaitu sebesar $43,47 \%$. Hasil terbaik dengan nilai $\mathrm{pH}$ sebesar 3,1 , pada kondisi operasi $250{ }^{\circ} \mathrm{C}$ dengan waktu pirolisis 60 menit.
\end{abstract}

Kata kunci : selulosa, hemiselulosa, lignin, pirolisis, dan asap cair

\begin{abstract}
Palm plantations in Indonesia began to grow rapidly since the early 80 s. The area of Indonesia's oil palm in 2013 was 10.4 million ha and increased $4.69 \%$ annually. The production of palm midrib was about 22 midribs per tree per year with the weight of midrib meat ranging from $2.2 \mathrm{~kg}$. The palm midrib is composed of cellulose, hemicellulose, and lignin, which can be used as liquid smoke. The purpose of this study was to analyze the effect of temperature and time of pyrolysis on the yield and quality of liquid smoke produced. The pyrolysis process of fractured palm was performed at $150{ }^{\circ} \mathrm{C}$, $200{ }^{\circ} \mathrm{C}$, and $250{ }^{\circ} \mathrm{C}$ for 30 minutes, 60 minutes, 90 minutes. The results indicated that the yield of liquid smoke tends to decrease with increasing pyrolysis temperature, and tends to increase with increasing pyrolysis time in which the difficult condensed gas production increases with increasing temperature and time of pyrolysis. The highest yield of liquid smoke pyrolysis temperature of $150{ }^{\circ} \mathrm{C}$ with pyrolysis time 120 minutes that is equal to $43.47 \%$. In this study, obtained the best results for a $\mathrm{pH}$ value of 3.1 is done at process temperatures of $250{ }^{\circ} \mathrm{C}$ with processing time 60 minutes
\end{abstract}

Keywords: cellulose, hemicellulose, lignin, pyrolysis, and liquid smoke

\section{Pendahuluan}

Perkebunan kelapa sawit di Indonesia mulai berkembang pesat sejak awal tahun 80-an dan saat ini kelapa sawit telah menjadi salah satu komoditas perkebunan yang berperan sangat penting [14]. Pada tahun 2013, luas areal kelapa sawit Indonesia adalah sebesar 10,4 juta ha dan meningkat 4,69 \% pada tahun berikutnya [4]. Selain menghasilkan CPO sebagai komoditas utama, industri kelapa sawit juga menghasilkan beberapa jenis hasil samping yang potensial salah satunya pelepah kelapa sawit (oil palm frond/ $O P F)$ [8].

Satu hektar kelapa sawit diperkirakan dapat menghasilkan 6400 - 7500 pelepah per tahun, sehingga di Sumatera Utara dengan luasan perkebunan kelapa sawit 2.400 .000 ha dapat menghasilkan sekitar 48.900.000 - 55.000.000 ton berat kering per tahun. [9]. Pelepah kelapa sawit tersusun atas selulosa, hemiselulosa, dan lignin [21]. Tanaman kelapa sawit (Elaeis guineensis Jacq) mulai berbuah 30 bulan setelah penyerbukan dan dapat dipanen jika tanaman telah berumur 31 bulan. Untuk memudahkan pemanenan, pelepah daun yang menyangga buah dipotong terlebih dahulu [5]. Berdasarkan jumlah limbah yang dihasilkan pada perkebunan sawit serta kandungan dari hemiselulosa, selulosa, dan lignin yang terkandung di dalam pelepah kelapa sawit, pelepah kelapa sawit berpotensi untuk dijadikan asap cair. Asap cair dapat diperloleh melalui pirolisis bahan baku yang mengandung 
hemiselulosa, selulosa, dan lignin yang telah dikondesasikan.

Pirolisis merupakan salah satu cara konversi secara termokimia serta memainkan peranan penting dalam konversi biomassa [7]. Pirolisis biomassa dapat dipengaruhi oleh empat faktor diantaranya kandungan air, dekomposisi hemiselulosa, dekomposisi selulosa dan lignin [7]. Berdasarkan uraian diatas, Tujuan dari penelitian ini adalah untuk mengetahui pengaruh temperatur, waktu pirolisis,dan kadar air terhadap rendemen dan $\mathrm{pH}$ asap cair yang dihasilkan.

\section{Teori}

Tanaman kelapa sawit berasal dari Nigeria, Afrika Barat. Tanaman ini merupakan tanaman perkebunan yang dominan di masyarakat Indonesia. Limbah adalah kotoran atau buangan yang merupakan komponen penyebab pencemaran terdiri dari zat atau bahan yang tidak mempunyai kegunaan lagi bagi masyarakat. Secara umum limbah kelapa sawit terbagi atas dua jenis yaitu limbah padat dan limbah cair. Jenis limbah kelapa sawit pada generasi pertama adalah limbah padat yang terdiri dari tandan kosong, pelepah, cangkang [20]. Pelepah kelapa sawit dihasilkan dari pemeliharaan tanaman diantaranya pembabatan, pemanenan buah dan peremajaan tanaman dengan memotong batang dan pelepah dari tanaman tersebut. Pelepah kelapa sawit termasuk kategori limbah basah (wet by-products) karena masih mengandung kadar air sekitar $75 \%$.

Pirolisis adalah dekomposisi termal yang terjadi dalam ketiadaan oksigen. Beberapa literatur juga menjelaskan bahwa pirolisis didefinisikan sebagai proses degradasi termal dari padatan dalam kondisi tidak adanya oksigen, yang memungkinkan terjadinya beberapa jalur konversi thermokimia sehingga padatan tersebut menjadi gas (permanent gasses), cairan (pyrolitic liquid) dan padatan (char) [6]. Ada banyak klasifikasi dari jenis-jenis pirolisis tergantung pada kondisi operasi, seperti laju panas, suhu, dan waktu tinggal uap. Sehingga, dapat diklasifikan secara umum yaitu pirolisis lambat (slow pyrolysis) dan pirolisis cepat (fast pyrolysis)[13]. Faktor- Faktor yang mempengaruhi proses pirolisis adalah waktu, suhu, ukuran partikel, dan berat partikel.

Asap cair merupakan senyawa-senyawa yang menguap secara simultan dari reaktor panas melalui teknik pirolisis (penguraian dengan panas) dan terkondensasi pada sistem pendingin [16]. Komposisi kimia dari asap cair terutama tergantung pada jenis kayu dan kadar air dari kayu, pengaruh kedua suhu pirolisis dan durasi generasi asap. Kualitas asap cair sangat bergantung pada komposisi senyawa-senyawa kimia yang terdapat dalam asap cair. Ada tiga senyawa yang mempengaruhi komposisi asap cair yaitu selulosa, hemiselulosa, dan lignin. Ketiganya jika mengalami pirolisa akan menghasilkan asam, fenol, karbonil, dan senyawasenyawa lain yang terdapat didalam asap cair. Kualitas aspa cair sangat bergantung pada komposisi komponen kimia yang terkandung didalam asap cair. Kandungan yang ada pada sap cair dipengaruhi oleh kondisi pirolisis dan jenis bahan baku. Senyawa asam karbosiklik merupakan senyawa yang paling banyak terkandung didalam asap cair, yang bergantung pada jumlah selulosa dan hemiselulosa pada bahan baku. Kandungan pada asap cair dipengaruhi oleh beberapa faktor diantaranya jenis bahan baku, kadar air, dan temperatur pembakaran yang digunakan [18]. Kualitas asap cair dapat ditentukan dengan menentukan kadar fenol dan asam karena kedua komonen tersebut mempunyai peranan yang sangat penting terhadap agen antimikroba. Kadar fenol dan asam yang tinggi pada asap cair, dapat menekan pertumbuhan mikroorganisme lebih cepat.

\section{Metodologi Penelitian \\ Pembuatan Asap Cair}

Pelepah sawit ditimbang sebanyak $1 \mathrm{~kg}$. Pelepah sawit dimasukkan ke dalam reaktor pirolisis. Pelepah sawit dipirolisis sesuai waktu dan suhu yang telah ditentukan, selanjutnya dikondensasikan. Asap cair ditampung dalam tangki penampungan. Asap cair di diamkan selama 2 × 24 jam. Asap cair disaring dengan kertas saring. Asap cair dianalisis

\section{Analisis Rendemen Asap Cair}

Asap cair yang dihasilkan dicatat volumenya. Asap cair dihitung massa jenisnya dengan menggunakan piknometer, sehingga didapatkan massa asap cair (A). Rendemen dihitung dengan Persamaan 1.

$$
\text { Rendemen }(\% \mathrm{~b} / \mathrm{b})=\frac{\mathrm{A}}{\text { berat bahan baku }} \times 100
$$

\section{Pengukuran pH [14]}

pH meter dicelupkan ke dalam aquadest. pH meter dibersihkan dengan tissue. $\mathrm{pH}$ meter dicelupkan kedalam asap cair. $\mathrm{pH}$ yg muncul di layar monitor dicatat sebagai $\mathrm{pH}$ asap cair.

\section{Hasil dan Pembahasan \\ Hasil Analisis Rendemen Asap Cair}

Rendemen asap cair adalah perbandingan antara massa asap cair yang dihasilkan terhadap massa pelepah kelapa sawit yang digunakan. Rendemen merupakan salah satu parameter yang penting untuk mengetahui hasil dari suatu proses. Temperatur pirolisis berpengaruh terhadap 
pemutusan ikatan kimia pada pelepah kelapa sawit. Semakin tinggi suhu pirolisis semakin banyak rendemen asap cair yang dihasilkan. Hal ini dikarenakan pelepah kelapa sawit mendapatkan jumlah panas yang cukup untuk terjadinya pemutusan ikatan kimia sehingga senyawa dalam pelepah kelapa sawit semakin banyak yang terurai dan terkondensasi menjadi asap cair [1].

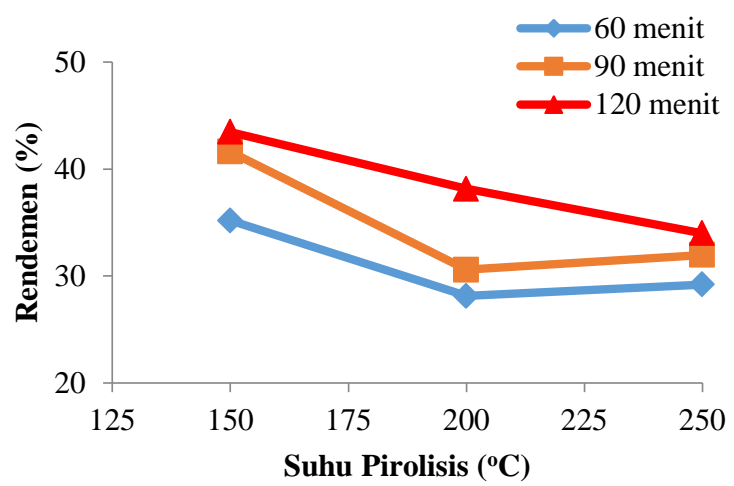

Gambar 1. Pengaruh Suhu Pirolisis Terhadap Rendemen Asap Cair

Gambar 1 menunjukkan rendemen asap cair yang diperoleh pada temperatur yang sama meningkat dengan bertambahnya waktu pirolisis. Hal ini disebabkan kontak panas dengan pelepah kelapa sawit menjadi lebih lama yang menyebabkan penigkatan konversi pelepah kelapa sawit $[1,11]$. Rendemen asap cair akan menurun dengan kenaikan temperatur, hal ini disebabkan oleh semakin tinggi suhu dan semakin lama waktu pirolisis juga dapat menyebabkan pembentukan gas yang tidak terkondensasi meningkat [11].

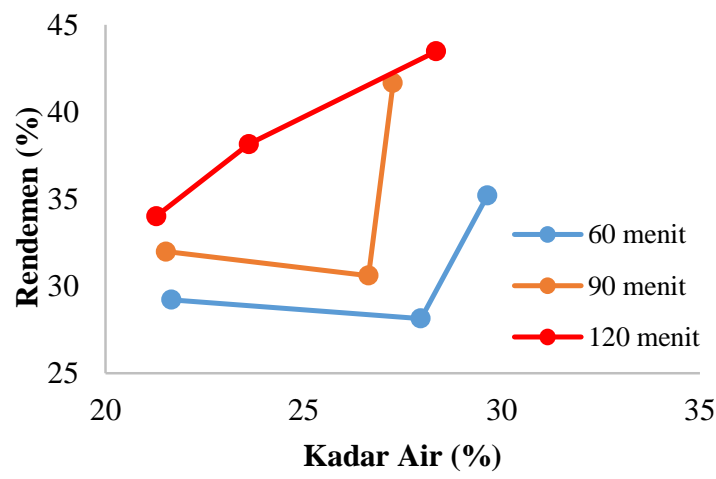

Gambar 2. Pengaruh Kadar Air Pelepah Kelapa Sawit terhadap Rendemen Asap Cair

Gambar 2 menunjukkan rendemen asap cair yang diperoleh meningkat seiring dengan meningkatnya kadar air bahan baku dan lama waktu pirolisis. Kadar air bahan baku dapat mempengaruhi rendemen yang dihasilkan. Pada saat proses pirolisis berlangsung kadar air yang terkandung di dalam bahan baku akan ikut menguap pada suhu $100^{\circ} \mathrm{C}$ dan mengalami kondensasi ketika uap air melalui kondensor sehingga meningkatkan jumlah kondensat asap cair yang dihasilkan [11].

\section{Hasil Analisis pH Asap Cair}

Kualitas asap cair yang dihasilkan dapat ditentukan dengan mengukur derajat keasaman (pH).

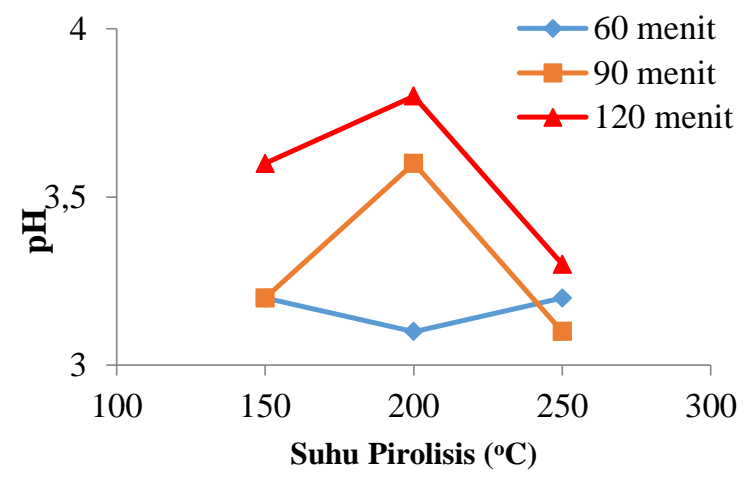

Gambar 3. Pengaruh Suhu Pirolisis Terhadap pH Asap Cair

Gambar 3 menunjukkan secara umum terjadi kenaikan $\mathrm{pH}$ asap cair pada rentang suhu $150^{\circ} \mathrm{C}$ sampai $200^{\circ} \mathrm{C}$. Hal ini disebabkan pada suhu pirolisis $150^{\circ} \mathrm{C}$ sampai $200^{\circ} \mathrm{C}$ total asam yang diperoleh lebih rendah karena kadar air dari pelepah kelapa sawit yang tinggi sehingga menurunkan kualitas asap cair yg dihasilkan [15]. Menurunnya kualitas asap cair akan mempengaruhi tingkat keasaman pada asap cair, sehingga nilai $\mathrm{pH}$ menjadi naik [15].

Pada suhu $200^{\circ} \mathrm{C}$ sampai $250^{\circ} \mathrm{C}$ terjadi penurunan $\mathrm{pH}$ asap cair. Hal ini disebabkan total asam yang diperoleh lebih tinggi dari pada kadar fenol sehingga asap cair yang dihasilkan sifatnya menjadi semakin asam. Semakin tinggi total asam yang terkandung didalam asap cair maka $\mathrm{pH}$ yang diperoleh akan semakin rendah, begitupun sebaliknya [15].

$\mathrm{pH}$ asap cair cenderung menurun dengan bertambahnya waktu pirolisis untuk suhu yang sama. Nilai pH akan menurun dengan meningkatnya waktu pirolisis. Hal ini dikarenakan banyaknya unsur-unsur yang terkandung didalam pelepah kelapa sawit yang terurai dan membentuk senyawa-senyawa asam. hasil pengukuran $\mathrm{pH}$ asap cair berkisar antara 3,1 dan 3,8. Harga $\mathrm{pH}$ tersebut menunjukkan bahwa produk asap cair bersifat asam.

Gambar 4 menunjukkan nilai $\mathrm{pH}$ asap cair yang diperoleh fluktuatif seiring dengan menigkatnya kadar air yang terkandung didalam pelepah kelapa sawit. Nilai $\mathrm{pH}$ asap cair yang 
diperoleh meningkat seiring dengan meningkatnya waktu pirolisis yang berarti kadar keasaman asap cair menurun. Nilai $\mathrm{pH}$ yang rendah berarti asap cair yang dihasilkan berkualitas tinggi terutama dalam hal penggunaanya sebagai bahan pengawet makanan. Pada proses pirolisis berlangsung kadar air yang terkandung didalam bahan baku akan ikut menguap pada suhu $100^{\circ} \mathrm{C}$ dan mengalami kondensasi ketika uap air melalui kondensor sehingga meningkatkan jumlah kondensat asap cair yang dihasilkan yang menurunkan kualitas dari asap cairp [11].

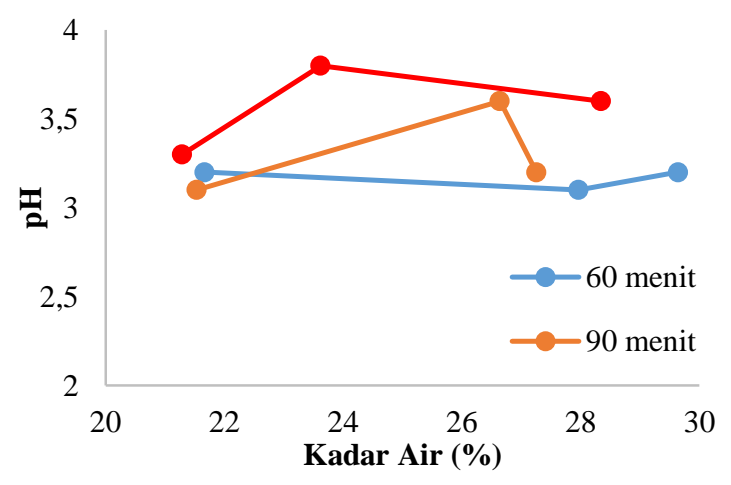

Gambar 4. Pengaruh Kadar Air Pelepah Kelapa Sawit terhadap Nilai pH Asap Cair

\section{Kesimpulan}

1. Suhu dan waktu pirolisis mempengaruhi rendemen asap cair yang diperoleh. Kenaikan waktu pirolisis akan menyebabkan rendemen asap cair yang diperoleh meningkat. Kenaikan suhu pirolisis akan menurunkan rendemen asap cair yang diperoleh.

2. Rendemen asap cair yang dihasilkan berkisar antara 29,20 \% dan 43,47\%. Rendemen tertinggi pada temperatur pirolisis $150{ }^{\mathrm{O}} \mathrm{C}$ selama 120 menit

3. $\mathrm{pH}$ asap cair yang diperoleh pada penelitian ini beriksar pada 3,1 dan 3,8 atau bersifat asam.

\section{Daftar Pustaka}

[1] A. Akbar, R. Paindoman, and P. Coniwanti, Pengaruh Variabel Waktu Dan Temperatur Terhadap Pembuatan Asap Cair Dari Limbah Kayu Pelawan (Cyanometra Cauliflora), vol. 19, no. 1, pp. 1-8, 2013.

[2] A. H. Iswanto, Karya Tulis Sifat Fisis Kayu : Berat Jenis dan Kadar Air Pada Beberapa Jenis Kayu, Departmen Kehutanan, Fakultas Pertanian, 2008.

[3] A. M. Mustafiah dan A. Aladin, Pengaruh Suhu terhadap Produksi Asap Cair dari Bleding Limbah Biomassa Cangkang Sawit dengan Batubara secara Pirolisis, Journal of Chemical Process Engineering Vol. 01, No.1, ISSN:2527-4457, 2016.

[4] Badan Pusat Statistik, Luas Areal, Produksi dan Produktivitas Perkebunan di Indonesia Tahun 2011 - 2015, 2015.

[5] Balai Besar Pengkajian Dan Pengembangan Teknologi Pertanian, Teknologi Budidaya Kelapa Sawit, 2008.

[6] C. Di Blasi, Modeling chemical and physical processes of wood and biomass pyrolysis, vol. 34, pp. 47-90, 2008.

[7] H. Yang, Characteristics of hemicellulose, cellulose and lignin pyrolysis, vol. 86, pp. 1781-1788, 2007.

[8] J. Elisabeth. dan S. P. Ginting, Pemanfaatan Hasil Samping Industri Kelapa Sawit Sebagai Bahan Pakan Ternak Sapi Potong, pp. 110-119, 2003.

[9] Junjungan, S. P. Ginting. dan K Simanihuruk, Utilization of Oil Palm Frond Silages as Basal Diet for Kacang Goats in Growth Phase, Semianar Nas. Teknol. Perternakan dan Vet., 446-455, 2008.

[10] K. Anisah, Analisa Komponen Kimia Dan Uji Antibakteri Asap Cair Tempurung Kelapa Sawit (Elaeis Guineensis Jacq) Pada Bakteri Staphylococcus Aureus Dan Pseudomonas Aeruginosa, Skripsi F. Kedokteran, UIN Syarif Hidayatullah Jakarta, 2014.

[11] M. Doni, R. Andoine, dan S. Nasir, Pengaruh Kondisi Operasi pada Pembuatan Asap Cair dari Tebu dan Serbuk Gergaji Kayu Kulim, Jurnal Teknik Kimia, No.4, Vol.15, 2008.

[12] M. Hermanto and S. Farizy, Karet Sebagai Koagulan Lateks, J. Tek. Kim, vol. 20, no. 4, pp. 14-21, 2014.

[13] N. Puy, J. D. Mart1, V. Navarro, dan A. M. Mastral, Waste tyre pyrolysis - A review, vol. 23, pp. 179-213, 2013.

[14] Pusat Data dan Sistem Informasi Pertanian, Informasi Ringkas Komoditas Pertanian Kelapa Sawit, No.01/01/I, 2013.

[15] R. Pamori , R. Efendi, dan F. Restuhadi Fume Characteristics Liquid Waste From The Pyrolysis Young Coconut Fiber, vol. 14, no. 2, pp. 43-50, 2015.

[16] R. Simon, B. de la Calle, S. Palme, D. Meier, dan E. Anklam, Composition and analysis of liquid smoke flavouring primary products, $J$. Sep. Sci, vol. 28, no. 9-10, pp. 871-882, 2005.

[17] R. Yulistiani, Asap Cair sebagai Bahan Pengawet Alami pada Produk Gading dan Ikan. Monograf UPN Veteran Jawa Timur, 2008. 
[18] S. P. A. Anggraini dan S. Yuniningsih, Utilization of Various Types of Agricultural Waste Became Liquid Smoke using Pyrolysis Process, vol. 28, pp. 60-66, 2014.

[19] Tranggono, Suhardi dan A.H. Setiaji., Produksi Asap Cair Beberapa Jenis Kayu Dan Penggunaannya Pada Pengolahan Beberapa Bahan Makanan Indonesia (Laporan Akir Riset Unggulan Terpadu). Jakarta:Menteri Riset dan Teknologi, 1997.

[20] Y. Ardila, Pemanfaatan Limbah Kelapa Sawit (Elaeis Guineensis Jaqs), Makalah Seminar Umum, Program Studi Agronomi Universitas Gajah Mada Yogyakarta, 2014.

[21] Y. Saragih, Padil, Produksi Nitroselulosa Sebagai Bahan Baku Propelan Yang Berbasis Limbah Padat Sawit, Laporan Penelitian Hibah Penelitian Stranas Batch II, Universitas Riau. 2009. 